\title{
Stable carbon isotope signatures of ancient Maize agriculture at El Kinel, Guatemala
}

\author{
Chris Balzotti \\ Plant and Wildlife Sciences \\ Brigham Young University, Provo
}

\author{
Charles Golden \\ Department of Anthropology, Brown Social Science \\ Center Brandeis University, Waltham
}

\author{
Richard E. Terry* \\ Plant and Wildlife Sciences \\ Brigham Young University, Provo
}

Stable $\mathrm{C}$ isotope studies of the soil organic matter (SOM) have delineated areas with histories of vegetation change from $\mathrm{C}_{3}$ forest to $\mathrm{C}_{4}$ maize (Zea mays L.) agriculture and back to the contemporary $\mathrm{C}_{3}$ forest. The objectives of this study were to: (1) determine if land around El Kinel, Guatemala possessed a vegetative history of shifts from $C_{3}$ forest to $C_{4}$ maize agriculture in the past, (2) determine if 10 years of contemporary maize production is sufficient time to deposit an isotopic signature of $\mathrm{C}_{4}$ plants in the root zone (top $40 \mathrm{~cm}$ ), and (3) to examine the extractable phosphorus concentrations and $\delta^{13} \mathrm{C}$ in soils of important archaeological features that included a midden, a burial, and two ancient reservoirs (aguadas). The lack of a shift in $\delta^{13} \mathrm{C}$ greater than $3.5 \%$ in the top $40 \mathrm{~cm}$ of the contemporary maize field suggested that continual maize cultivation of more than ten years is required to create an isotopic signature for maize agriculture. Carbon isotopic evidence was found in soil profiles to confirm that long-term agriculture was practiced by ancient Maya farmers at El Kinel. The man-made aguadas did not show isotopic shifts greater than $2.3 \%$ in any part of the profile, indicating they were used for other purposes not associated with $\mathrm{C}_{4}$ plant growth. The relatively low $\mathrm{P}\left(<30 \mathrm{mg} \mathrm{kg}^{-1}\right)$ was found in soil at the same depth but at a distance of $30 \mathrm{~cm}$ from an ancient burial. The high $\mathrm{P}$ concentration $\left(127 \mathrm{mg} \mathrm{kg}^{-1}\right)$ found within millimeters of the bones implied that the $\mathrm{P}$ enrichment came from the remains but $\mathrm{P}$ remained fixed in the soil and did not migrate.

Key words: $\mathrm{C}_{3}$ and $\mathrm{C}_{4}$ plants, humin, rhizodeposition, Maya archaeology, phosphorus

\author{
Addresses: Ch. Balzotti, R. E. Terry: Provo, UT 84602, USA, \\ Corresponding author's e-mail: richard_terry@byu.edu \\ Ch. Golden: Waltham, MA 02453, USA, e-mail: cgolden@brandeis.edu \\ A. Scherer: Box 1921; Brown University, Providence, RI 02912, USA, \\ e-mail: andrew scherer@brown.edu \\ Received: March 31, 2013; accepted: June 6, 2013
}




\section{Introduction}

Archaeology like many other disciplines is ever evolving and becoming more of a multidisciplinary field. Soil geochemistry is one tool that has been used to discover anthropogenic residues of ancient activities (Entwistle et al. 2000; Terry et al. 2004; Holliday and Gartner 2007). The focus of this paper is the use of stable carbon isotopes of the soil organic matter (SOM) to find the signatures of ancient vegetation shifts from native forest growth to forest clearance for maize (Zea mays L.) agriculture. A brief description of the effects of shifts from $\mathrm{C}_{3}$ forest vegetation to $\mathrm{C}_{4}$ plants associated with maize agriculture are provided along with sample collection and preparation methods. Soil pedons from recently cleared maize fields were used in a case study of isotopic signatures of contemporary and ancient maize agriculture on the border of Guatemala and Mexico at El Kinel (Fig. 1).

In the absence of agricultural structures such as terraces it is difficult to discover land use strategies and agricultural methods that sustained the ancient Maya. Stable carbon isotope analyses of skeletal remains have provided evidence that

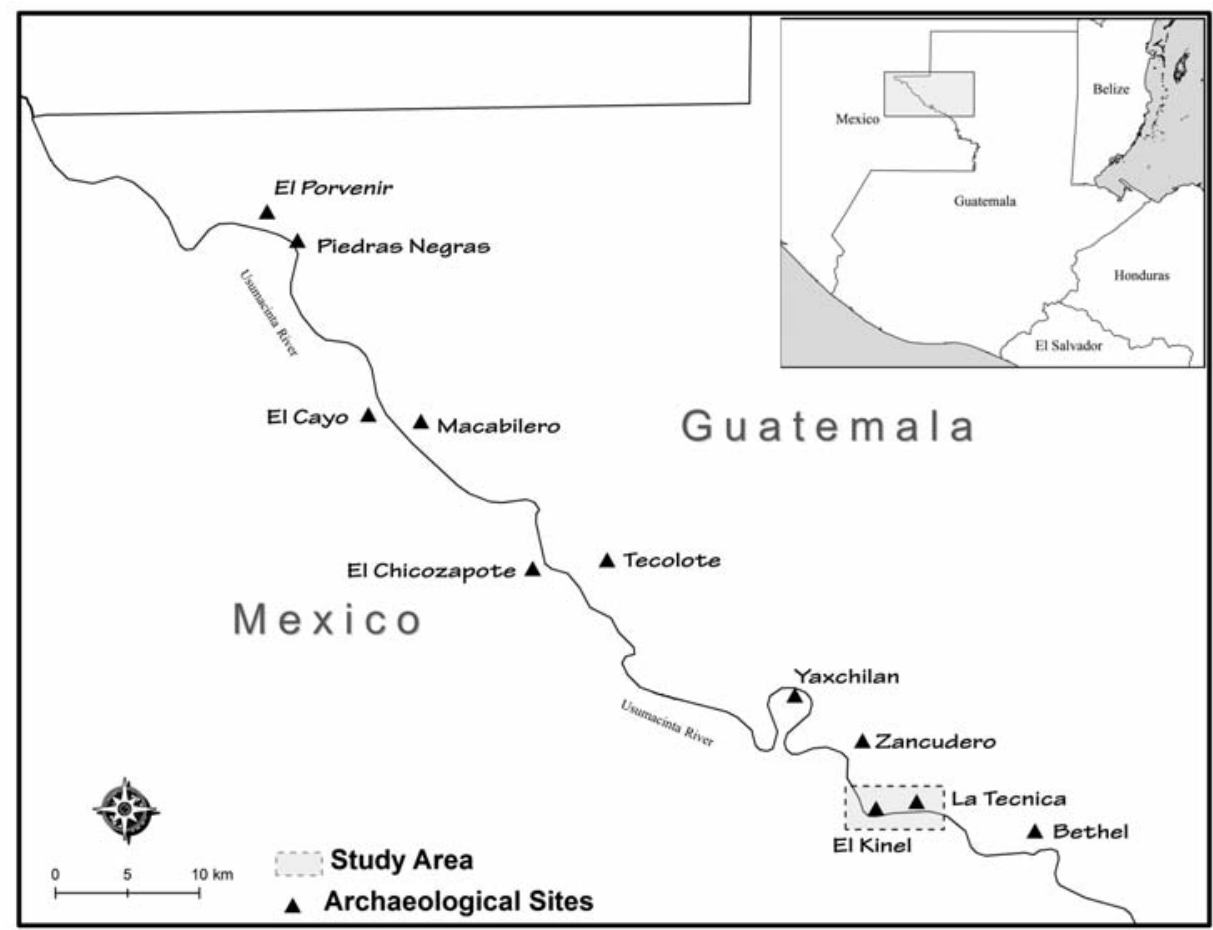

Fig. 1

Map of the Usumacinta River basin on the border of Guatemala and Mexico. The locations of the sites of El Kinel and La Técnica are shown 
maize, a $\mathrm{C}_{4}$ plant, was an important food source among the ancient Maya populations (Wright and White 1996; Tykot 2002; Scherer et al. 2007; López et al. 2011). However, skeletal remains do not inform us how or where the food was produced. One of the reasons that it is difficult to understand where agriculture took place is the lack of prehispanic records (Wilken 1971). Additionally, agricultural activities seldom left architectural or artifactual evidence to be discovered (Burnett et al. 2012a; Burnett et al. 2012b). Further complicating our understanding of food production is the immense area and the diverse landscapes occupied by the ancient Maya. The paucity of archaeological evidence for ancient agricultural activities has led to multiple hypotheses on the subject of Maya food production ranging from widespread deforestation for swidden culture of maize, to maize as a supplement to ramon nut and other crops (Folan et al. 1979; Puleston 1982).

To gain a better understanding of where ancient agriculture took place in Mesoamerica and the Caribbean basin, stable $\mathrm{C}$ isotope studies of the SOM have been applied to delineate areas with histories of vegetation change from $\mathrm{C}_{3}$ forest to $\mathrm{C}_{4}$ maize agriculture and back to the contemporary $\mathrm{C}_{3}$ forest (Lane et al. 2004; Webb et al. 2004; Fernandez et al. 2005; Johnson et al. 2007; Webb et al. 2007; Beach et al. 2008; Wright et al. 2009; Burnett et al. 2012a b).

\section{Stable carbon isotopes and root zone SOM}

The idea behind using stable C isotopes in SOM for identification of ancient maize agriculture is based in the differing isotopic discrimination against heavy carbon $\left({ }^{13} \mathrm{C}\right)$ between plants commonly associated with forests versus many of the tropical grasses (Farquhar et al. 1989b). Plants that utilize the Hatch-Slack pathway $\left(\mathrm{C}_{4}\right.$, grasses) for carbon assimilation discriminate less against ${ }^{13} \mathrm{CO}_{2}$ than those that use the Calvin Cycle $\left(C_{3}\right.$, woody plants) (Smith and Epstein 1971; Farquhar et al. 1982; Cerling et al. 1997). Atmospheric $\mathrm{CO}_{2}$ contains 1.1 atom percent ${ }^{13} \mathrm{C}$ (Farquhar et al. 1982; Farquhar et al. 1989a). Plant membranes and photosynthetic pathways isotopically discriminate against the heavier ${ }^{13} \mathrm{CO}_{2}$ (compared to that of ${ }^{12} \mathrm{CO}_{2}$ ), making their $\delta^{13} \mathrm{C}$ lower than that of the atmosphere (Farquhar et al. 1982). Plant isotopic discrimination against ${ }^{13} \mathrm{C}$ is defined as the ratio of ${ }^{13} \mathrm{C}$ to ${ }^{12} \mathrm{C}$ compared to that of the standard, Pee Dee Belemnite (PDB) (Cerling et al. 1997):

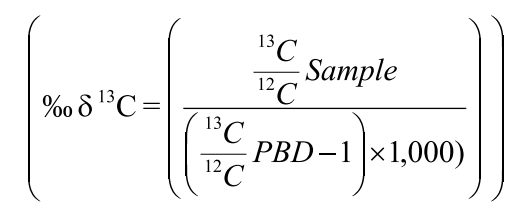

Under the current atmospheric $\mathrm{CO}_{2}$ mixing-ratio and ${ }^{13} \mathrm{CO}_{2}$ conditions, $\mathrm{C}_{3}$ plants have an overall $\delta^{13} \mathrm{C}$ of -30 to $-20 \%$ with an average of $-27 \%$ o compared 
to that of the $\mathrm{C}_{4}$ plants with $\delta^{13} \mathrm{C}$ values of -14 to $-10 \%$ averaging $-12 \%$ (Bender 1968; Cerling et al. 1997; Liu et al. 1997).

Deposition of ${ }^{13} \mathrm{C}$ from the plant to the $\mathrm{SOM}$ is accomplished by decomposition of above-ground tissues (Balesdent et al. 1988), below-ground biomass, and rhizodeposition (Kuzyakov and Domanski 2000; Amos and Walters 2006) (Fig. 2). The overall contribution of $\mathrm{C}$ to the SOM from above-ground tissues, belowground biomass and rhizodeposition varies. After a 15-year study, Bolinder et al. (1999) gave estimates for C incorporated from maize above-ground and belowground biomass to the SOM at 7.7 to $20 \%$ and 16 to $30 \%$, respectively. This and other studies have shown that a greater portion of maize carbon retained in the SOM originated from roots than from shoots (Balesdent and Balabane 1996; Molina et al. 2001). Rhizodeposition continually contributes C into the SOM accounting for $5-21 \%$ of all photosynthetically fixed carbon released into the soil (Marschner 1995). Furthermore, in an anthropogenic setting where crops are removed from the field the above-ground biomass contribution could be even lower than the above listed values.

Once the plant carbon is incorporated into the pool of SOM, the isotopic signature is preserved, though microbial digenesis may cause an isotopic

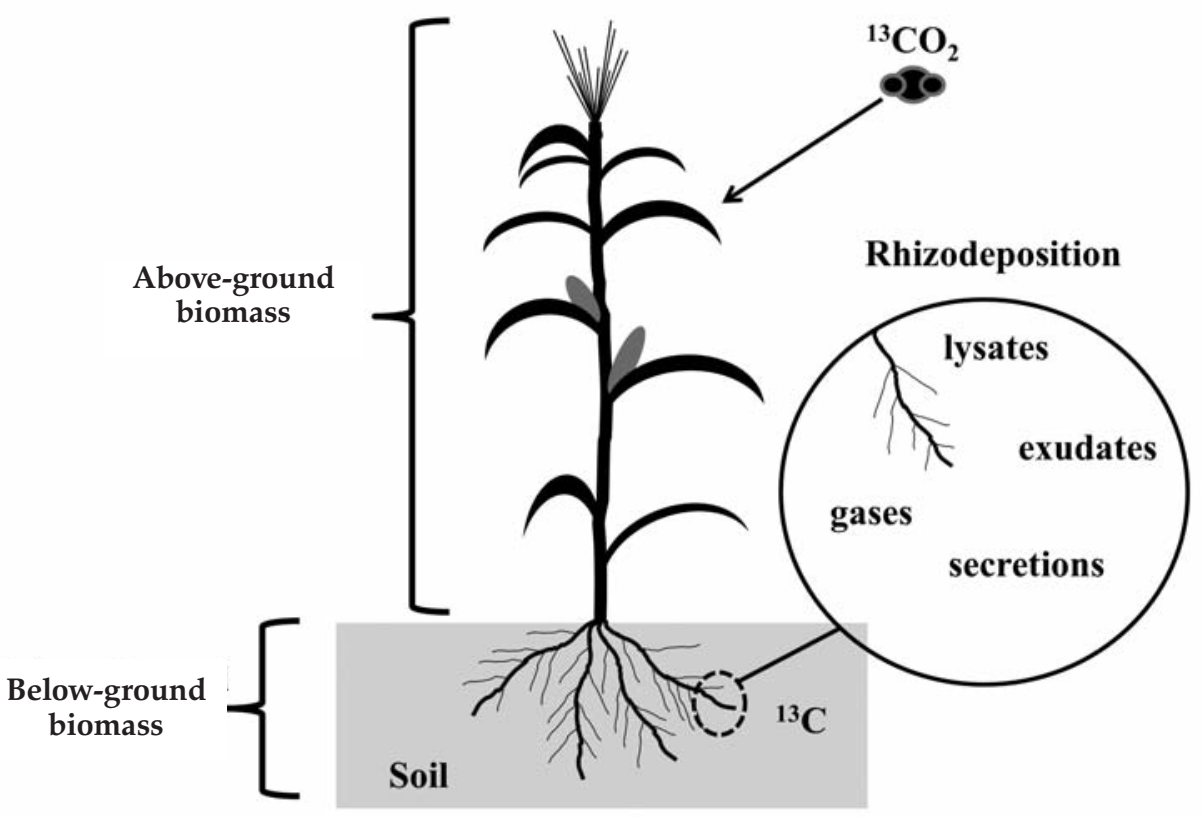

Fig. 2

Deposition of ${ }^{13} \mathrm{C}$ from a maize plant to the SOM is accomplished by decomposition of above-ground tissues, below-ground biomass, and rhizodeposition 
enrichment in ${ }^{13} \mathrm{C}$ of about 2.5\%o (Balesdent and Mariotti 1987; Agren et al. 1996; Boutton 1996; Cerling et al. 1997). The amount of time it takes to "create" an isotopic signature of vegetation type in the soil is not fully understood. However, soil composition and environmental conditions influence the amount of time needed for an isotopic signature to change. For example, Vitorello et al. (1989) found that twelve years after a forest $\left(C_{3}\right.$ plants) was converted to $C_{4}$ sugarcane (saccharum), $90 \%$ of the carbon in the clay fraction still had the forest signature, demonstrating the ability of the clay to preserve the isotopic signature. A more in depth review of the process of ${ }^{13} \mathrm{C}$ deposition by maize can be found in Balzotti et al. (2013).

\section{Case study of agriculture soils at El Kinel}

The Usumacinta valley between Guatemala and Mexico has provided valuable soil resources for the ancient Maya as well as for contemporary Maya farmers. The flood plain soils reach depths of over $3 \mathrm{~m}$ and are relatively free of rock. Soils of the valley have been examined in profile at archaeological test pits and in addition soil pedons have been examined by bucket auger collection. A pedon is defined as an individual soil, whereas a soil profile in an archaeological pit can be viewed as undisturbed soil horizons. Soil properties and the $\delta^{13} \mathrm{C}$ of horizons from 39 soil pedons near the sites of El Porvenir, Piedras Negras and the Rio Macabilero drainage have been reported (Fernandez et al. 2005; Johnson et al. 2007). These sites are on the Guatemalan side of the Usumacinta River and extend north from El Kinel to within $20 \mathrm{~km}$ of the Mexican border to the north (Fig. 1). These studies have identified ancient maize agricultural activity on the Usumacinta River Basin. The $\delta^{13} \mathrm{C}$ results suggested that there are strong signatures of $\mathrm{C}_{4}$ plants, such as maize and tropical grasses in many of the soils, especially in the foot and toeslopes throughout the study area. Further, the current soil conditions and extent of relatively gently sloped areas are favorable for agriculture. Overall, the results are supportive of the hypothesis that the area, located between the polities of Piedras Negras and Yaxchilán, was agriculturally important to the surrounding region.

The archaeological site El Kinel, found near the contemporary village of La Técnica, Guatemala (Fig. 3), is located in a modern maize field where local farmers have cultivated maize for 10 continuous years without the addition of fertilizers or pesticides (Golden and Scherer 2006; Houston et al. 2006; Golden et al. 2008). Neighbouring farms outside the river valley with shallow karst soils are fortunate if they produce for 3 continuous years without a fallow period. This unique ability of flood plain soils to sustain maize cultivation provided an opportunity to determine whether 10 years of continual maize production is sufficient to shift the isotopic signature more than $3.5 \%$ in this area.

Local farmers from the nearby community of La Técnica cleared the site of El Kinel for agricultural use starting in the 1990s. The deep alluvial soils at the site 


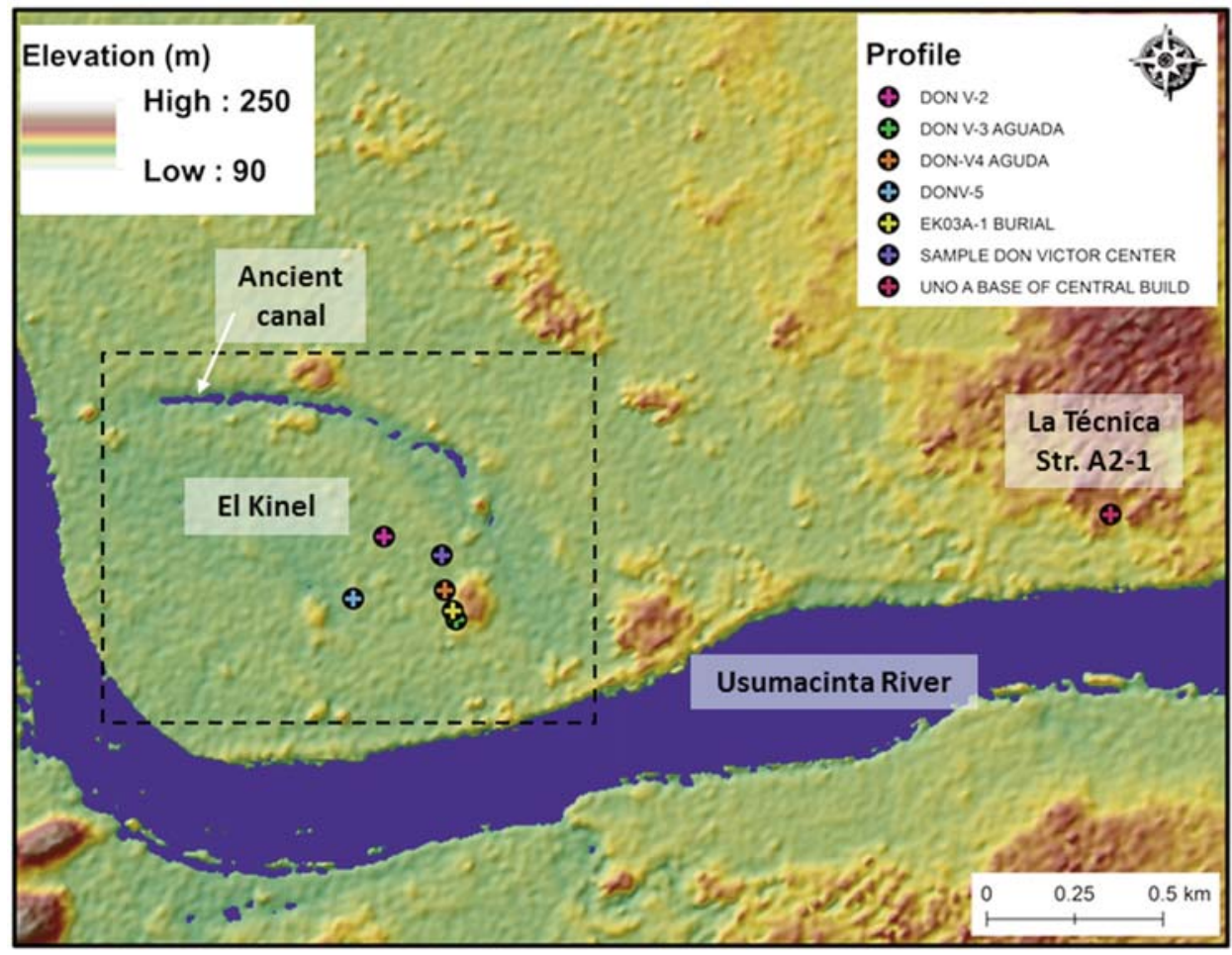

Fig. 3

Digital elevation model of the sites of El Kinel and La Técnica, Guatemala on the banks of the Usumacinta River. The locations of soil pedons and the ancient canal are shown

had sustained maize agriculture for 10 years prior to sampling in 2006 (Don Victor Ramirez Carreto, personal communication). The ancient canal at the site (Fig. 4) could have functioned as both a water-management feature and a defensive feature (Houston et al. 2006). The canal separates land at a bend in the river from the mainland and anciently would have created an island before the canal was largely filled by sediment.

Rooting depths for maize vary and can reach beyond $1 \mathrm{~m}$. However, in a review by Amos and Walters (2006) it was reported that between $70-90 \%$ of the root biomass can be found in the top of $0.3 \mathrm{~m}$ of the soil (Aina and Fapohunda 1986; Crozier and King 1993; Dwyer et al. 1996). At the site of El Kinel archaeologists only encountered cultural material below depths of 30 to $40 \mathrm{~cm}$ in test pits. It is likely that much of the site was buried in nearly $40 \mathrm{~cm}$ of flood sediment during the past 1100 years of abandonment. Therefore, a shift in $\delta^{13} \mathrm{C}$ from the surface to $0.4 \mathrm{~m}$ in this study can be attributed to modern maize ${ }^{13} \mathrm{C}$ input. 
The objective of this study was to: (i) determine if the areas in and around El Kinel showed a shift from $\mathrm{C}_{3}$ to $\mathrm{C}_{4}$ plants in the past, (ii) determine if 10 years of contemporary maize production is sufficient time to deposit a $\mathrm{C}_{4}$ signature in the root zone (top $40 \mathrm{~cm}$ ), and (iii) examine the extractable phosphorus concentrations and ${ }^{13} \mathrm{C}$ of important archaeological features such as a waste midden, a burial (subsequently covered in midden material), and two small water catchment reservoirs (aguadas).

\section{Materials and Methods}

\section{Soil pedon collection}

Five soil pedons at El Kinel were collected by bucket auger and examined. Three sampling locations within the contemporary maize field were thought to have high agricultural potential based on low slope, deep soils, short distance to water, and proximity to ancient structures (Don V-center, Don V-2 and Don V-5). Two pedons thought to have low agricultural potential were collected in the silted remains of two small reservoir basins, called aguadas, near the highest concentration of structures (Don V-3 and Don V-4). The aguadas are depression areas that currently contain wetland vegetation. Agricultural and aguada soil samples were collected with an 8 -cm diameter bucket auger at $15-\mathrm{cm}$ depth increments, beginning with the surface. For each agriculture and aguada pedons a depth of one to three-m was reached providing between 10 and 20 samples per pedon with an overall total of 86 horizon samples. The soil horizon characteristics of two profiles were examined within archaeological test pits. Horizon samples were collected at $10-\mathrm{cm}$ depth intervals from open archeological pits near structures: a midden at the base of Structure A2-1 at La Técnica (Quiroa et al. 2006) and a midden that contained a burial at El Kinel (Pérez Robles and Arroyave 2007: 42-43; Burial 3; Fig. 3). Soil samples contained in polyethylene bags were transported to the Brigham Young University Environmental Analysis Laboratory (Provo, UT). The slope and elevation of the profile and pedon locations were measured on site, using a clinometer and on computer by a digital elevation model (DEM) generated from data collected by Airborne Synthetic Aperture Radar (AIRSAR) (Evans et al. 1986) and Shuttle Radar Topography Mission (SRTM) (Farr et al. 2007). The same DEM data were used to determine the landscape position of each soil. The Universal Transverse Mercator (UTM) coordinates of each pedon and profile were recorded in the field.

\section{Laboratory Analysis}

Samples were air-dried and crushed to pass a $2 \mathrm{~mm}$ (10 mesh) sieve. Soil texture was determined using the hydrometer method of Gee and Bauder (1986). The $\mathrm{pH}$ of each surface horizon $(\sim 0-15 \mathrm{~cm})$ was determined on a 1:2 soil to water mixture by glass electrode. The Mehlich extractable phosphorus (P) levels were also 


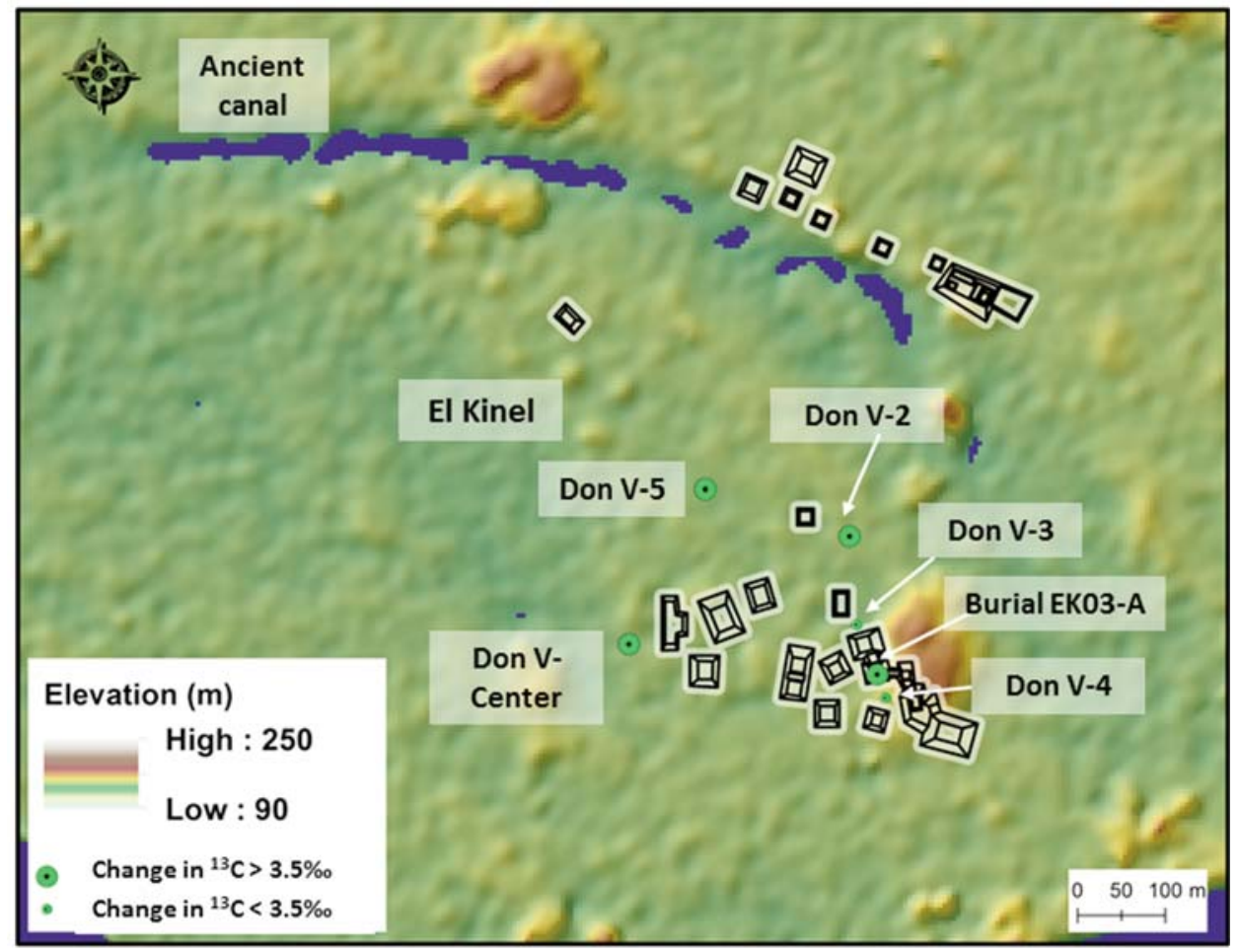

Fig. 4

Digital elevation model and map of the site of El Kinel, Guatemala. The locations of structures, soil pedons and the ancient canal are shown

measured for those same horizons (Terry et al. 2000). Five-gram sub-samples were further ground to pass a $250 \mu \mathrm{m}(60 \mathrm{mesh})$ sieve in preparation for stable C isotope analyses.

Carbonates were removed from the 60-mesh samples by reaction with excess $\mathrm{HCl}$ and rinsing, prior to $\mathrm{C}$ isotope analysis. Researchers have raised concern that some pre-analysis acidification procedures for removal of carbonates cause significant, non-systematic bias in the isotope analysis (Brodie et al. 2011). To address these concerns, samples were centrifuged at high speed $(>30,000 \times g$ for more than 1 hour) after acidification and after rinsing with water. Based on the findings of Webb et al. (2004) that the humin fraction would be the most sensitive detector of ancient $\mathrm{C}_{4}$ vegetation in this type of environment, the humic acid and fulvic acid fractions were removed by alkaline pyrophosphate extraction following Webb et al. (2004; 2007) and Wright et al. (2009). The stable C isotope ratios of the humin fraction of the SOM of each soil horizon were determined by isotope-ratio mass spectrometer (Thermo Finnigan Delta V, Waltham, MA) coupled with an elemental analyzer (EAIRMS) (Costech, Valencia, CA). The 
standard deviation of six replicate analyses of $\delta^{13} \mathrm{C}$ was $0.27 \%$. The stable C isotope values of the humin fractions were reported as $\delta^{13} \mathrm{C}$ in per mil notation $(\%)$.

The absolute value of the largest shift in $\delta^{13} \mathrm{C}$ values between surface and subsurface horizons was reported for each pedon as the change in $\delta^{13} \mathrm{C}$. This value represents the amount of ${ }^{13} \mathrm{C}$ enrichment in each soil and was the primary indicator used to measure the effects of past vegetation changes on the SOM.

\section{Results}

Surface samples from the contemporary maize field pedons (Don V-Center, Don V-2 and Don V-5) were enriched in ${ }^{13} \mathrm{C}$ by an average of $1.5 \%$ and none of the three pedons exhibited $\delta^{13} \mathrm{C}$ shifts greater than $3.5 \%$ in the top $40-\mathrm{cm}$ zone of maximum root activity (Fig. 5). However, all three possessed shifts greater than $3.5 \%$ in the lower depths that were likely associated with changes in vegetative history. The greatest shift was found in pedon Don V-5 (5.1\%o) at the 67-cm depth (Fig. 5). A second shift in $\delta^{13} \mathrm{C}$ was $4.0 \%$ was observed at the 202-cm depth. Shifts of more than $3.5 \%$ were found at depths of 115 and $283 \mathrm{~cm}$ in pedon Don V-

Fig. 5

The change in $\delta^{13} \mathrm{C}$ with soil depth of the humin fraction of pedons Don VCenter, Don V-2 and Don V-5. These pedons were located in a field cropped to maize for 10 years

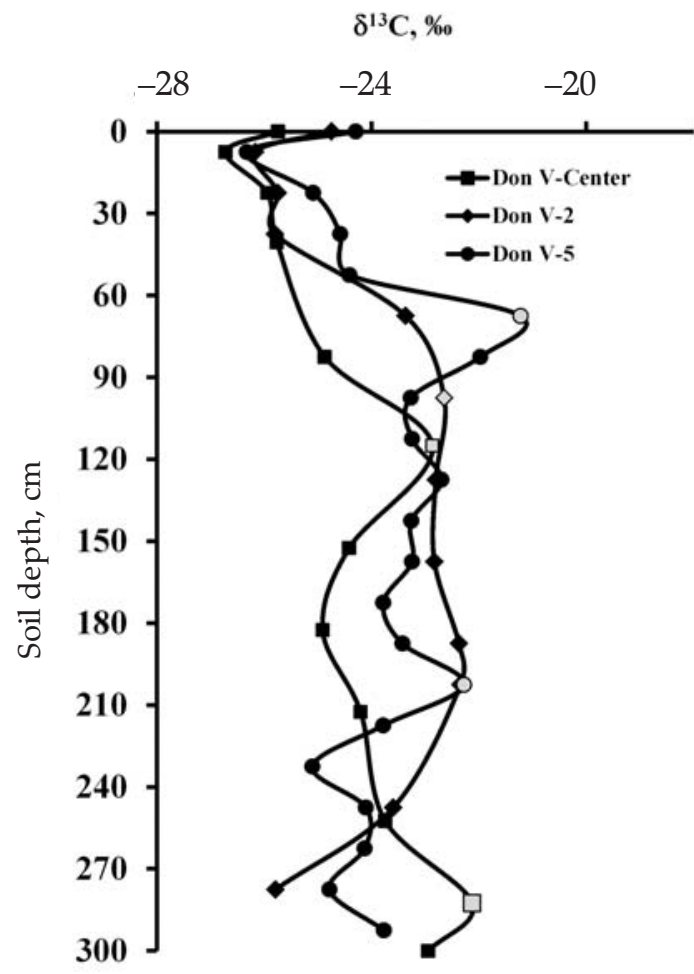

Central European Geology 56, 2013 


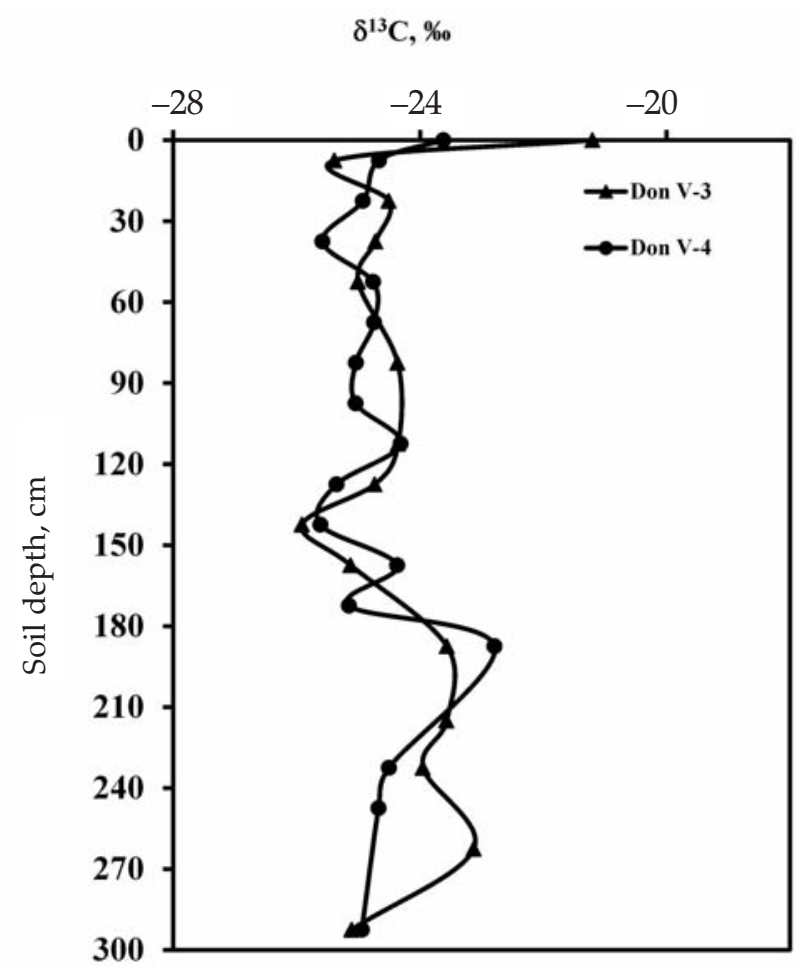

Fig. 6

The change in $\delta^{13} \mathrm{C}$ with soil depth of the humin fraction of pedons Don V-3 and Don $\mathrm{V}-4$. These pedons were located in two ancient water reservoirs adjacent to house mounds at the site of $\mathrm{El}$ Kinel

Center and at depths of 97 and $202 \mathrm{~cm}$ in pedon Don V-2 (Fig. 5). These shifts in $\delta^{13} \mathrm{C}$ below the contemporary zone of maximum rooting activity suggest ancient shifts in vegetation from forest to maize agriculture at two periods in antiquity.

Neither of the pedons from the aguadas (Don V-3 and Don V-4) exhibited shifts in $\delta^{13} \mathrm{C}$ greater than $3.5 \%$ at any depth (Fig. 6). The greatest shift in $\delta^{13} \mathrm{C}$ was $2.3 \%$ in pedon Don V-3 at a depth of $262 \mathrm{~cm}$. The soil profiles exposed at two test pits located in middens adjacent to structures at El Kinel (Burial 3) and nearby La Técnica (Str. A2-1) were examined for changes in extractable $\mathrm{P}$ and ${ }^{13} \mathrm{C}$ enrichment with depth. The structures and test pits were higher in elevation (Fig. 2) and were not affected as much by flood deposition. Midden material was found to a depth of $110 \mathrm{~cm}$ at the base of structure A2-1 at La Técnica. The extractable P concentrations in the profile exceeded $120 \mathrm{mg} \mathrm{kg}^{-1}$ at the 40 to $80-\mathrm{cm}$ depth (Fig. 7). Soil in this midden possessed the signature of $C_{4}$ vegetation in all but the surface $10 \mathrm{~cm}$. A burial was found at the bottom of the test pit at El Kinel (EK-03 A) (Pérez Robles and Arroyave 2006). The midden material above the burial at El Kinel was enriched in $P$ ranging from 23 to $30 \mathrm{mg} \mathrm{kg}^{-1}$ at the 40 to $60-\mathrm{cm}$ depths. Soil at the same depth as the burial but $30 \mathrm{~cm}$ away from the bones was low in $\mathrm{P}$, ranging from 10 to $16 \mathrm{mg} \mathrm{kg}^{-1}$. However, a separate soil sample taken adjacent to the shoulder bones of the burial contained $127 \mathrm{mg} \mathrm{kg}^{-1} \mathrm{P}$. 

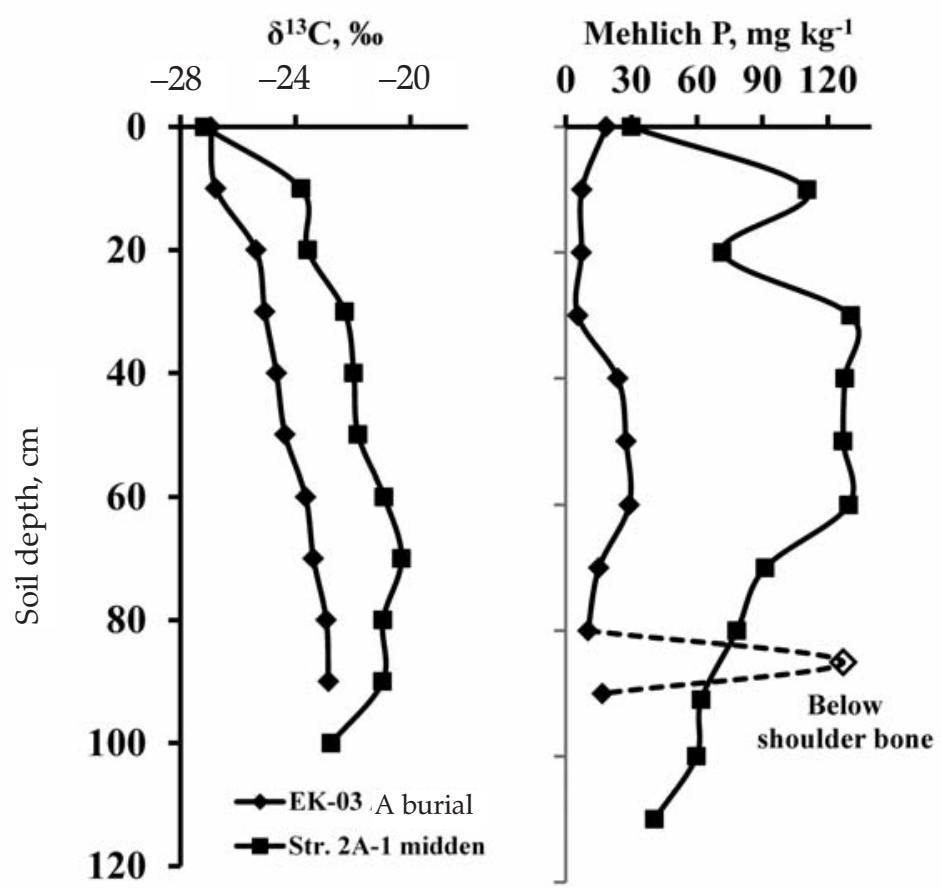

Fig. 7

The changes in Mehlich extractable P concentration $\left(\mathrm{mg} \mathrm{kg}^{-1}\right)$ and in $\delta^{13} \mathrm{C}(\% \circ)$ with profile depth of midden test pits at La Técnica Structure A2-1 and at burial EK-03 A

\section{Discussion}

None of the modern maize field pedons showed shifts greater than $3.5 \%$ in the zone of maximum root activity for maize (top $40 \mathrm{~cm}$ ). This lack of shifts suggest that continual maize cultivation of greater than 10 years would be required to deposit sufficient ${ }^{13} \mathrm{C}$ into the SOM.

Enrichment in ${ }^{13} \mathrm{C}$ greater than $3.5 \%$ at the 67 to $115-\mathrm{cm}$ depths and again at the 2 to 3-m depths of the contemporary maize field pedons suggested ancient shifts in vegetation from forest to maize agriculture at two periods in antiquity. The two $C_{4}$ vegetation shifts with intervening $C_{3}$ forest vegetation provided evidence of maize cultivation during the Preclassic period and again in the Classic Maya period, about 3000 to 1700 years before present (BP) and about 1400 to 1100 years $\mathrm{BP}$, respectively.

Archaeologists excavated a $1 \mathrm{~m} \times 1 \mathrm{~m} \times 3$-m deep test pit at the location of the aguada pedon Don V-3 (Pérez Robles and Arroyave 2006: 47). No artifacts were 
found in the test pit until the 3-m depth was reached. Beach sands were found at that depth with several large potsherds. It can reasonably be assumed that the normally flooded aguada soils have never been used in maize agriculture and serve as a comparison for the background change in $\delta^{13} \mathrm{C}$ attributed to flood deposited sediments. The lack of $\delta^{13} \mathrm{C}$ shifts greater than $3.5 \%$ within the aguadas further validates the lack of maize agriculture in these features.

The soil $\mathrm{P}$ accumulation and ${ }^{13} \mathrm{C}$ enrichment in the two midden test pits suggested that significant portions of the waste materials in the middens were high in both $\mathrm{P}$ and in ${ }^{13} \mathrm{C}$ from $\mathrm{C}_{4}$ plant-derived foodstuffs. The low $\mathrm{P}$ concentration at the depth of the burial but $30 \mathrm{~cm}$ from the bones compared to soils collected within millimeters of the bones illustrated that $\mathrm{P}$ became fixed to soil particles and did not move more than a few $\mathrm{cm}$ from its source in the soil. The change in $\delta^{13} \mathrm{C}$ of more than $3.5 \%$ was observed at the 70 - to $90-\mathrm{cm}$ depths, closest to the burial. The midden materials, residues from the burial and organic matter from ancient maize agriculture were sources of the ${ }^{13} \mathrm{C}$ enrichment but the proportional contributions of each source are not known. No modern fertilizers had been used in or around the site suggesting that the P enrichment of the midden and burial profiles was from the deposition of food and other waste materials. The relatively low $\mathrm{P}$ content $\left(<30 \mathrm{mg} \mathrm{kg}^{-1}\right)$ of soil above and below the burial, the high $\mathrm{P}$ concentrations $\left(127 \mathrm{mg} \mathrm{kg}^{-1}\right)$ found within millimeters of the bones implies that the $\mathrm{P}$ enrichment came from the remains. Phosphorus remained fixed in the soil within the burial and did not migrate.

\section{Conclusions}

Combined with the proximity to residential structures, deep soils, and high agricultural potential, the pedons Don V-Center, Don V-2 and Don V-5 yielded carbon isotopic evidence that long-term agriculture was practiced by the ancient inhabitants of El Kinel. Furthermore, the man-made aguadas did not show isotopic shifts of vegetation change, indicating they were used for purposes other than maize cultivation. The lack of a shift in $\delta^{13} \mathrm{C}$ greater than $3.5 \%$ in the top 40 $\mathrm{cm}$ of the contemporary maize field suggested that continual maize cultivation of more than ten years is required in this region to create an isotopic signature for maize agriculture in the SOM. These data confirm that the soils of the Usumacinta valley were important agriculture resources that sustained the ancient Maya.

\section{Acknowledgements}

Funding for this research was from the Brigham Young University Mentored undergraduate research program. The 2006 Field Season of the Proyecto Regional Arqueológico Sierra del Lacandón was directed by Luis Castillo, Rosaura Vásquez, Charles Golden and Andrew Scherer, supported by grants from the H. John Heinz III Charitable Trust Grant for Archaeology, the National Geographic Society, 
Stable carbon isotope signatures of ancient Maize agriculture at El Kinel, Guatemala 71

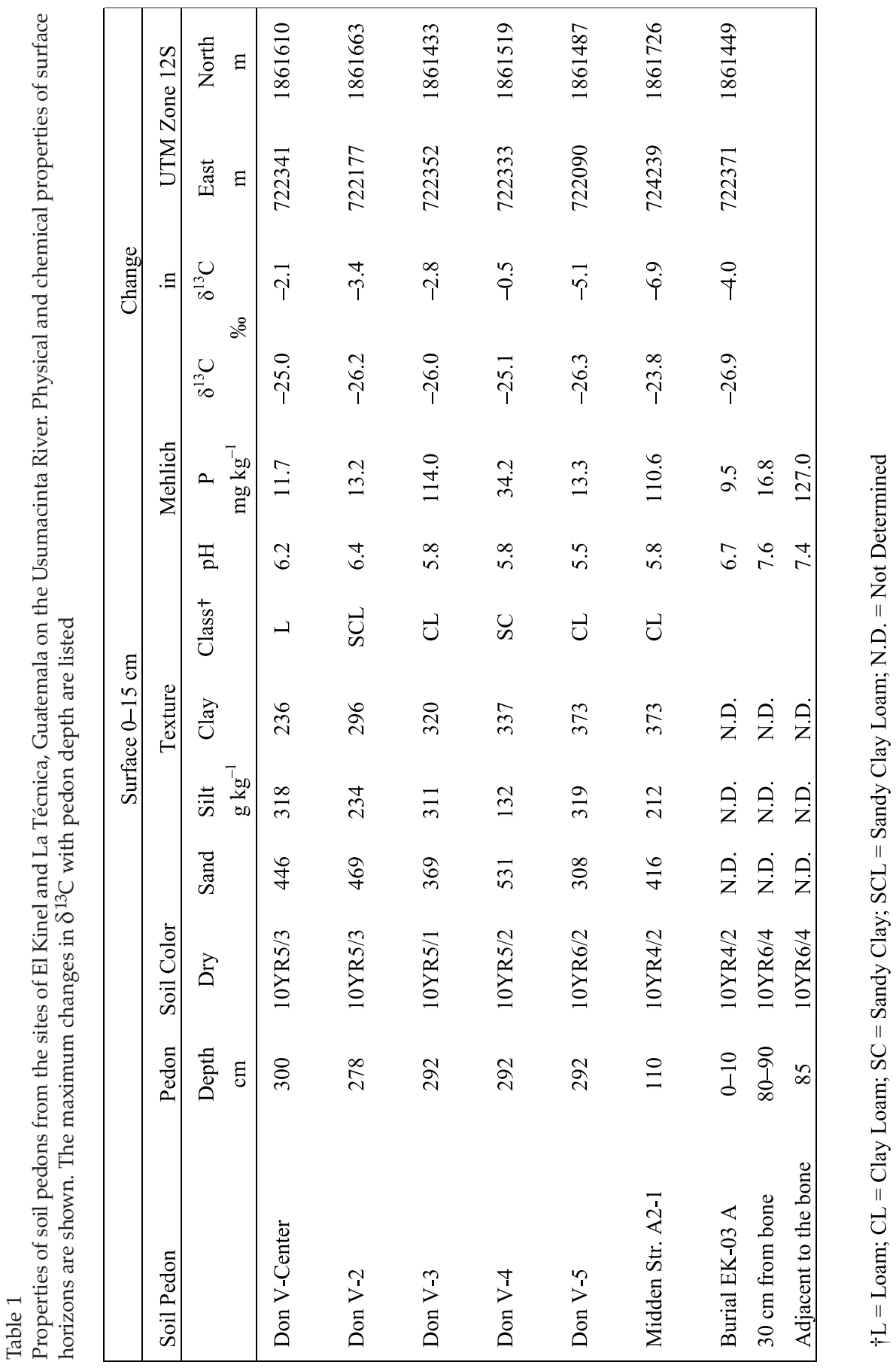

Central European Geology 56, 2013 
Brandeis University and Wagner College. The work was permitted by Instituto de Antropología e Historia de Guatemala. Permission to sample the maize field was from Don Victor Ramírez Carreto La Técnica, Guatemala. The excellent sample preparation and analytical work of Environmental Science students at BYU is appreciated.

\section{References}

Agren, G.I., E. Bosatta, J. Balesdent 1996: Isotope discrimination during decomposition of organic matter: A theoretical analysis. - Soil Science Society of America Journal, 60, pp. 1121-1126.

Aina, P.O., H.O. Fapohunda 1986: Root distribution and water-uptake patterns of maize cultivars field-grown under differential irrigation. - Plant and Soil, 94/2, pp. 257-265.

Amos, B., D.T. Walters 2006: Maize root biomass and net rhizo-deposited carbon: an analysis of the literature. - Soil Science Society of America Journal 70, pp. 1489-1503.

Balesdent, J., A. Mariotti 1987: Natural ${ }^{13} \mathrm{C}$ abundance as a tracer for studies of soil organic matter dynamics. - Soil Biology and Biochemistry, 19, pp. 25-30.

Balesdent, J., G.H. Wagner, A. Mariotti 1988: Soil organic matter turnover in long-term field experiments as revealed by carbon-13 natural abundance. - Soil Science Society of America Journal, 52, pp. 118-124.

Balesdent, J., M. Balabane 1996: Major contribution of roots to soil carbon storage inferred from maize cultivated soils. - Soil Biology and Biochemistry, 28, pp. 1261-1263.

Balzotti, C.S., D. Webster, T. Murtha, S.L. Petersen, R.L. Burnett, R.E. Terry 2013: Modeling the ancient maize agriculture potential of landforms in Tikal National Park. - Guatemala International Journal of Remote Sensing 34/16, pp. 5868-5891.

Beach, T., S. Luzzadder-Beach, N. Dunning, D. Cook 2008: Human and natural impacts on fluvial and karst depressions of the Maya Lowlands. - Geomorphology, 101/1-2, pp. 308-331.

Bender, M.M. 1968: Mass spectrometric studies of carbon-13 variations in corn and other grasses. Radiocarbon, 10, pp. 468-472.

Bolinder, M.A., D.A. Angers, M. Giroux, M.R. Laverdiere 1999: Estimating C inputs retained as soil organic matter from corn (Zea mays L.). - Plant and Soil, 215, pp. 85-91.

Boutton, T. 1996: Stable carbon isotope ratios of soil organic matter and their uses as indicators of vegetation and climate change. - In: Boutton, T.W., S. Yamasaki (Eds): Mass Spectrometry of Soils, Marcel Dekker Inc., New York, pp. 47-82.

Brodie, C.R., M.J. Leng, J.S.L. Casford, C.P. Kendrick, J.M. Lloyd, Y.Q. Zong, M.I. Bird 2011: Evidence for bias in $\mathrm{C}$ and $\mathrm{N}$ concentrations and delta $\mathrm{C}-13$ composition of terrestrial and aquatic organic materials due to pre-analysis acid preparation methods. - Chemical Geology, 282/3-4, pp. 67-83.

Burnett, R.L., R.E. Terry, M. Alvarez, C. Balzotti, T. Murtha, D. Webster, J. Silverstein 2012a: The ancient agricultural landscape of the satellite settlement of Ramonal near Tikal, Guatemala. Quarternary International, 265, pp. 101-115.

Burnett, R.L., R.E. Terry, R.V. Sweetwood, T. Murtha, D. Webster, J. Silverstein 2012b: Upland and lowland soil resources of the ancient Maya at Tikal, Guatemala. - Soil Science Society of American Journal, 76/6, pp. 2083-2096.

Cerling, T.E., J.M. Harris, B.J. MacFadden, M.G. Leakey, J. Quade, V. Eisenmann, J.R. Ehleringer 1997: Global vegetation change through the Miocene/Pliocene boundary. - Nature 389/6647, pp. $153-158$.

Crozier, C.R., L.D. King 1993: Corn root dry-matter and nitrogen distribution as determined by sampling multiple soil cores around individual plants. - Communications in Soil Science and Plant Analysis, 24/11-12, pp. 1127-1138.

Dwyer, L.M., B.L. Ma, D.W. Stewart, H.N. Hayhoe, D. Balchin, J.L.B. Culley, M. McGovern 1996: Root mass distribution under conventional and conservation tillage. - Canadian Journal of Soil Science, $76 / 1$, pp. 23-28. 
Entwistle, J.A., R.A. Dodgshon, P.W. Abrahams 2000: An investigation of former land-use activty through the physical and chemical analysis of soils from the Isle of Lewis, Outer Hebrides. Archaeological Prospection, 7, pp. 171-188.

Evans, D.l., T.g. Farr, J.P. Thompson, C.L. Werner 1986: Multipolarization Radar Images for Geologic Mapping and Vegetation Discrimination. - Geoscience and Remote Sensing, 24/2, pp. 246-257.

Farquhar, G.D., J.R. Ehleringer, K.T. Hubick 1989a: Carbon isotope discrimination and photosynthesis. - Annual Review of Plant Physiology and Molecular Biology, 40, pp. 503-537.

Farquhar, G.D., K.T. Hubick, A.G. Condon, R.A. Richards 1989b: Carbon isotope fractionation and plant water-use efficiency. - In: Rundel, P.W., J. R. Ehleringer, K.A. Nagy (Eds): Stable Isotopes in Ecological Research, Springer Verlag, New York, pp. 21-40.

Farquhar, G.D., M.H. O'Leary, J.A. Berry 1982: On the relationship between carbon isotope discrimination and the intercellular carbon dioxide concentration in leaves. - Australian Journal of Plant Physiology, 9, pp. 121-137.

Farr, T.G., P.A. Rosen, E. Caro1, R. Crippen, R. Duren, S. Hensley, M. Kobrick, M. Paller, E. Rodriguez, L. Roth, D. Seal, S. Shaffer, J. Shimada, J.Umland, M. Werner, M.l Oskin, D. Burbank, D. Alsdorf 2007: The Shuttle Radar Topography Mission. - Reviews of Geophysics, 45/2, DOI: 10.1029/2005RG000183

Fernandez, F.G., K.D. Johnson, R.E. Terry, S. Nelson, D. Webster 2005: Soil resources of the ancient Maya at Piedras Negras, Guatemala. - Soil Science Society of American Journal, 69, pp. 2020-2032.

Folan, W.J., L.A. Fletcher, E.R. Kintz 1979: Fruit, fiber, bark and resin: social organization of a Maya urban center. - Science, 204, pp. 697-701.

Gee, G.W., J.W. Bauder 1986: Particle-size analysis. - In: Klute, A. (Ed.): Methods of soil analysis. Part 1, 2nd ed. vol. 9. Soil Science Society of America, Madison, pp. 383-411.

Golden, C., A.K. Scherer 2006: Border problems: Recent archaeological research along the Usumacinta River. - The PARI Journal 7, pp. 1-16.

Golden, C., A.K. Scherer, A.R. Munoz, R. Vasquez 2008: Piedras Negras and Yaxchilan: divergent political trajectories in adjacent Maya polities. - Latin American Antiquity, 19/3, pp. 249-274.

Holliday, V.T. W.G. Gartner 2007: Methods of soil P analysis in archaeology. - Journal of Archaeological Science, 34, pp. 301-333.

Houston, S., H. Escobedo, C. Golden, A.K. Scherer, R. Vasquez, A.L. Arroyave, F. Quiroa, J.C. Melendez 2006: La Technica and El Kinel: Mounds and a monument upriver from Yaxchilan. Mexicon 28, pp. 87-93.

Johnson, K.D., R.E. Terry, M.W. Jackson, C. Golden 2007: Ancient soil resources of the Usumacinta River Region, Guatemala. - Journal of Archaeological Science 34, pp. 1117-1129.

Kuzyakov, Y., G. Domanski 2000: Carbon input by plants into the soil. Review. - Journal of Plant Nutrition and Soil Science-Zeitschrift für Pflanzenernahrung und Bodenkunde 163, pp. $421-431$.

Lane, C.S., S.P. Horn, C.I. Mora 2004: Stable carbon isotope ratios in lake and swamp sediments as a proxy for prehistoric forest clearance and crop cultivation in the Neotropics. - Journal of Paleolimnology, 32, pp. 375-381.

Liu, R., C.E. Clapp, H.H. Cheng 1997: Usefulness of the carbon-13 tracer technique for characterizing terrestrial carbon pools. - Nutrient Cycling in Agroecosystems 49, pp. 261-266.

López, C.M., L.F. Núnez, P. Morales, E. Cienfuego, F. Otero 2011: Diet and health at Chinikihá, Chiapas, Mexico: some preliminary results. - Environmental Archaeology, 16/2, pp. 82-96.

Marschner, H. 1995: Mineral nutrition of higher plants. - 2nd ed. Academic Press, London.

Molina, J.A.E., C.E. Clapp, D.R. Linden, R.R. Allmaras, M.F. Layese, R.H. Dowdy, H.H. Cheng 2001: Modeling the incorporation of corn (Zea mays L.) carbon from roots and rhizodeposition into soil organic matter. Soil Biology and Biochemistry 33, pp. 83-92.

Pérez Robles, G., A.L. Arroyave 2006: Excavaciones en El Kinel, Grupo Sur: Operación 3. - In: Proyecto Regional Arqueologico Sierra del Lacandon, 2006, Informe de la Cuarta Temporada de 
Campo, edited by C. Golden, A. K. Scherer and R. Vasquez, Instituto de Antropologia e Historia, Guatemala, pp. 40-61.

Puleston, D.E. 1982: The role of ramón in Maya subsistance. - In: Flannery, K.V. (Maya Subsistence: Studies in Memory of Dennis E. Puleston. Academic Press Inc., New York, pp. 353-366.

Quiroa, F, F. María, A.L. Arroyave 2006: Excavaciones en La Técnica. - In Proyecto Regional Arqueologico Sierra del Lacandon, 2006, Informe de la Cuarta Temporada de Campo, edited by C. Golden, A. K. Scherer and R. Vasquez. Instituto de Antropologia e Historia, Guatemala, pp. $15-25$.

Scherer, A.K., L.E. Wright, C.J. Yoder 2007: Bioarchaeological evidence for social and temporal differences in diet at Piedras Negras, Guatemala. - Latin American Antiquity, 18/1, pp. 85-104

Scherer, A.K., C. Golden 2009: Tecolote, Guatemala: Archaeological evidence for a fortified late classic Maya political border. - Journal of Field Archaeology, 34/3, pp. 285-305.

Smith, B.N., S. Epstein 1971: Two categories of ${ }^{13} \mathrm{C} /{ }^{12} \mathrm{C}$ ratios for higher plants. - Plant Physiology, 47, pp. 380-384.

Terry, R.E., P.J. Hardin, S.D. Houston, M.W. Jackson, S.D. Nelson, J. Carr, J. Parnell 2000: Quantitative phosphorus measurement: A field test procedure for archaeological site analysis at Piedras Negras, Guatemala. - Geoarchaeology: An International Journal, 15, pp. 151-166.

Terry, R.E., F.G. Fernández, J.J. Parnell, T. Inomata 2004: The story in the floors: chemical signatures of ancient and modern Maya activities at Aguateca, Guatemala. - Journal of Archaeological Science 31, pp. 1237-1250.

Tykot, R.H. 2002: Contribution of stable isotope analysis to understanding dietary variation among the Maya. - In: Jakes, K.A. (Ed.): Archaeological Chemistry: Materials, Methods, and Meaning. ACS Symposium Series. vol. 831, pp. 15-25.

Vitorello, V.A., C.C. Cerri, F. Andreux, C. Feller, R.L. Victoria 1989: Organic matter and natural carbon13 distribution in forested and cultivated Oxisols. - Soil Science Society of American Journal, 53/3, pp. 773-778.

Webb, E., H. Schwarcz, C.T. Jensen, R.E. Terry, M.D. Moriarty, K.F. Emery 2007: Stable carbon isotopes signature of ancient maize agriculture in the soils of Motul de San José, Guatemala. Geoarchaeology: An International Journal 22, pp. 291-312.

Webb, E.A., H.P. Schwarcz, P.F. Healy 2004: Carbon isotope evidence for ancient maize agriculture in the Maya lowlands. - Journal of Archaeological Science, 31, pp. 1039-1052.

Wilken, G.C. 1971: Food-producing systems available to the ancient Maya. - American Antiquity, 36, pp. 432-448.

Wright, D.R., R.E. Terry, M. Eberl 2009: Soil properties and stable carbon isotope analysis of landscape features in the Petexbatún region of Guatemala. - Geoarchaeology: An International Journal, pp. 24, 466- 491.

Wright, L.E., C.D. White 1996: Human biology in the classic Maya collapse: Evidence from paleopathology and paleodiet. - Journal of World Prehistory 10, pp. 147-198. 